\title{
The first troglomorphic pseudoscorpion of the family Olpiidae (Pseudoscorpiones), with remarks on the composition of the family
}

\author{
Mark S. Harvey ${ }^{1,2}$ and Mei Chen Leng' \\ 'Department of Terrestrial Zoology, Western Australian Museum, Locked Bay 49, \\ Welshpool DC, Western Australia 6986. Australia. Email: mark.harvey@museum.wa.govau. \\ 'School of Animal Biology, University of Western Australia, Crawley, Western Australia 6009, Australia.
}

\begin{abstract}
A new genus and species of Olpiidae, Limatolpium limari, is described from a pisolite mesa in the Pilbara region of Western Australia. The sole specimen exhibits troglomorphic facies with highly reduced eyes, pallid colouration and slightly attenuated appendages, differing from all other cavedwelling olpiids which lack troglomorphic facies. The affinities of the new genus are difficult to determine, but it is most similar to a group of genera characterised by the position of trichobothrium isb: Pseudohorus, Austrohorus, Xenolpium, Euryolpium and possibly Heterolpium. The family Olpiidae is divided into two subfamilies, Olpiinae and Hesperolpiinae.
\end{abstract}

\section{INTRODUCTION}

Pseudoscorpions of the family Olpiidae are virtually cosmopolitan in distribution, usually occurring in xeric environments under rocks, in leaf litter or beneath the bark of trees. Cavedwelling olpiids are, however, quite rare, with only five species recorded from subterranean habitats: Calocheirus tenerifae Mahnert 2002 from the Canary Islands (Mahnert 2002), and Progarypus gracilis Mahnert 2001, P. liliae Mahnert 2001, P. nigrimanus Mahnert 2001, and P. setifer Mahnert 2001 from Brazil (Mahnert 2001). All of these species have large eyes and seem to exhibit no troglomorphic morphological modifications.

Among specimens collected from subterranean habitats within mesas in the Pilbara region of Western Australia was a single male of an unusual olpiid. The specimen has reduced eyes, is slightly pale in colouration, and has slightly attenuate appendages. To further document the subterranean pseudoscorpion fauna of Western Australia we present a description of this species based upon a single male specimen. We also propose a division of the Olpiidae into two subfamilies, Olpiinae and Hesperolpiinae, based primarily upon the length of the venom ducts.

The specimen examined in the present study is lodged in the Western Australian Museum, Perth (WAM). Terminology and mensuration mostly follows Chamberlin (1931), with the exception of the nomenclature of the chelicera (Judson 2007), pedipalps, legs and with some minor modifications to the terminology of the trichobothria (Harvey 1992). In particular, it should be noted that the terminology for the trichobothria used by Harvey (1992) differs slightly from that used by other workers. The setal notation of metatarsus IV follows Muchmore
(1986), who based his system on the observations of Heurtault (1980a, 1980b, 1982) and Heurtault and Rebière (1983).

The specimen was examined with an Olympus BH-2 compound microscope and illustrated with the aid of a drawing tube. Measurements were taken at the highest possible magnification using an ocular graticule. The specimen was examined by preparing a temporary slide mount by immersing the specimen in $20 \%$ lactic acid at room temperature for several days, and mounting it on a microscope slide with 10 or $12 \mathrm{~mm}$ coverslips supported by small sections of $0.25 \mathrm{~mm}$ or $0.50 \mathrm{~mm}$ diameter nylon fishing line. After study the specimen were returned to $75 \%$ ethanol with the dissected portions placed in $12 \times 3 \mathrm{~mm}$ glass genitalia microvials (BioQuip Products, Inc.). Images of the whole animal were taken using a Micropublisher 5.0 digital camera mounted on a Leica MZ16 microscope.

\section{Family Olpiidae Banks 1895}

\section{Subfamily Olpiinae Banks 1895}

\section{Remarks}

For most of the past 80 years, the Olpiidae were defined by a series of characters states outlined by Chamberlin (1930, 1931) and Beier (1932). Although numerous new genera have been described since the 1930's, the family definition has barely altered. The Olpiidae were recently restricted by Judson $(1992,1993)$ by the removal of the garypinines to a separate family, Garypinidae, and the removal of the hesperolpiines as a subfamily of Garypidae. The status of the garypinines as a family was confirmed by Judson (2005), who referred to his unpublished thesis (Judson 1992) in defining the group. With the exclusion of the garypinines from 
the family Olpiidae, and the transfer of a further five genera (Neominniza Beier 1930, Oreolpium Benedict and Malcolm 1978, Protogarypinus Beier 1954, Teratolpium Beier 1959 and Thaumatolpium Beier 1931) from the Olpiidae to the Garypinidae by Harvey and Štáhlavský (unpublished data), the family now contains 33 genera (Table 1).

Hoff (1945) divided the Olpiinae into the tribes Olpiini Banks 1895 and Xenolpiini Hoff 1945 based upon the morphology of the first pair of legs in which the femur are longer than the patella in Olpiini, with a freely moveable joint, but the two segments are subequal in Xenolpiini, thus allowing only restricted movement. Both tribes were rediagnosed by Hoff (1964), but were subsequently used only intermittently by later researchers. They were abandoned by Heurtault (1980b), who presented new data on the type species of several Old World genera, including the type genera of the two tribes, Olpium L. Koch 1873 and Xenolpium Chamberlin 1930. In particular, Heurtault (1979, 1980a, 1980b) found

Table 1 Genera assigned to the Olpiidae.

Family Olpiidae Banks 1895

Subfamily Olpiinae Banks 1895

Antillolpium Muchmore 1991

Austrohorus Beier 1966

Banksolpium Muchmore 1986

Beierolpium Heurtault 1977

Calocheiridius Beier and Turk 1952

Euryolpium Redikorzev 1938

Halominniza Mahnert 1975

Heterolpium Sivaraman 1980

Hoffhorus Heurtault 1977

Horus Chamberlin 1930

Indolpium Hoff 1945

Leptolpium Tooren 2002

Linnaeolpium gen. nov.

Minniza Simon 1881

Neopachyolpium Hoff 1945

Nipponogarypus Morikawa 1955

Novohorus Hoff 1945

Olpiolum Beier 1931

Olpium L. Koch 1873

Pachyolpium Beier 1931

Parolpium Beier 1931

Pseudohorus Beier 1946

Xenolpium Chamberlin 1930

Subfamily Hesperolpiinae Hoff 1964 Aphelolpium Hoff 1964

Apolpium Chamberlin 1930

Calocheirus Chamberlin 1930

Cardiolpium Mahnert 1986

Ectactolpium Beier 1947

Hesperolpium Chamberlin 1930

Nanolpium Beier 1947

Planctolpium Hoff 1964

Progarypus Beier 1931

Stenolpiodes Beier 1959

Stenolpium Beier 1955 that the type species of Xenolpium, X. pacificum (With 1907) from New Zealand, possessed leg morphology characteristic of the Olpiini requiring the automatic synonymy of the two tribes. In the meantime, Hoff (1964) included a third tribe - Hesperolpiini Hoff 1964 - within the Olpiinae based upon the long venom ducts within the chelal fingers, and the patella of leg I shorter than the femur, with a freely mobile joint. Hoff (1964) included Hesperolpium and Aphelolpium within the Hesperolpiini, which was augmented by the inclusion of Planctolpium Hoff 1964 by Muchmore (1979), previously described as a member of the Garypidae (Hoff 1964). Long venom ducts are also found in a variety of other olpiids: Apolpium Chamberlin 1930 (Chamberlin 1931; Tooren 2002; Harvey, personal observation), Calocheirus Chamberlin 1930 (Mahnert 1986, 2002), Cardiolpium Mahnert 1986 (Mahnert 1986), Ectactolpium Beier 1947 (Harvey, personal observation), Nanolpium Beier 1947 (Harvey, personal observation), Progarypus Beier 1931 (Mahnert 2001; Harvey,

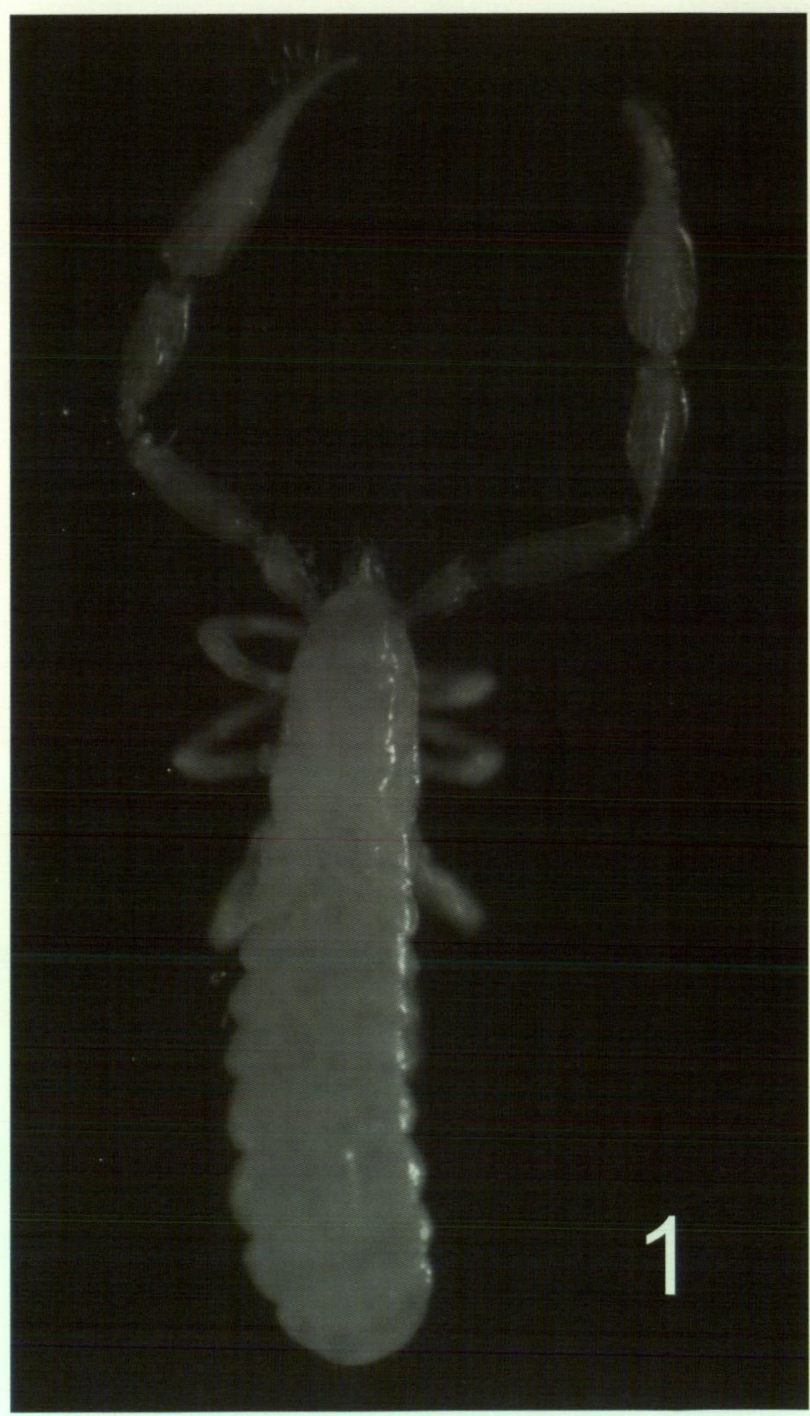

Figure 1 Linnaeolpium linnaei sp. nov., holotype male (WAM T82354). 
personal observation), Stenolpiodes Beier 1959 (Harvey, personal observation) and Stenolpium Beier 1955 (Mahnert 1984; Harvey, personal observation). All of these genera, along with Aphelolpium, Hesperolpium and Planctolpium, are here regarded as hesperolpiines, based upon the criteria explicitly outlined by Hoff (1964).

Although we concur with Heurtault (1979, $1980 \mathrm{a}, 1980 \mathrm{~b})$ that a satisfactory division between the Olpiini and Xenolpiini is unobtainable, we agree with Hoff (1964) that the hesperolpiines appear to represent a distinct diagnosable entity, which is here recognised as a subfamily of the Olpiidae. The proposal by Judson (1992, 1993) that the Hesperolpiinae represents a member of the Garypidae remains untested (but see below). The Hesperolpiinae contains 11 genera, whereas the relimited Olpiinae contains 22 genera (Table 1). Nearly all Olpiinae possess short venom ducts where they generally do not reach et in the fixed chelal finger or $t$ in the moveable chelal finger. The most obvious exception is Minniza barkhannae Mahnert 1991 from Saudi Arabia, in which the venom ducts are quite elongate (Mahnert 1991). The distinctiveness of the hesperolpiines is further emphasized by the results of Murienne et al. (2008) who, using molecular sequence data from two nuclear ribosomal genes and one mitochondrial protein-encoding gene, found that the three hesperolpiines used in the study (Apolopium paroum Hoff 1945, Nanolpium sp. and Progarypus sp.), formed a clade with the olpiine Pachyolpium sp., whereas the remaining olpiines (Beicrolpium bornemisszai (Beier 1966), Calochoiridius termitophilus Beier 1964, Euryolpium sp. and Xenolpium sp.) formed a monophyletic clade that was sister to Garypidae (Anagarypus heatwolei Muchmore 1982 and Synsphyromus apimelus Harvey 1987). This phylogeny was found with the combined analysis of (a) the $18 \mathrm{~S}$ rRNA, 285 rRNA and COI data, and (b) the 18S rRNA and $28 S$ rRNA data. The COI analysis found Garypidae grouping with Pachyolpium sp. and Apolpium paroum, with Nanolpium sp. and Progarypus sp. grouping with the remaining olpiines. The placement of Pachyolpium sp. with the hesperolpiines argue against the proposed division of the Olpiidae into two subfamilies, but presumably further molecular markers and additional taxa may help to resolve this conundrum.

Further research into the affinities of both olpiid subfamilies is necessary. The olpiines and hesperolpiines share a number of morphological features with other garypoid families: the short venom ducts found in olpiines are also found in Menthidae and some Garypinidae (all genera except Amblyolpium Simon 1898 and Neoamblyolpium Hoff 1956), and the long venom ducts characteristic of the Hesperolpiinae are also found in Geogarypidae, Garypidae, Larcidae and some Garypinidae (Amblyolpimm and Neomblyolpium). The lack of any features providing firm evidence for the monophyly of the Olpiidae suggests that the Olpiinae and Hesperolpiinae may not be sister taxa, concordant with the analyses of Murienne if al. (2008), and that other character systems need to be explored to establish their affinities and status within the Garypoidea.

\section{Genus Linnaeolpium gen. nov.}

\section{Type species}

Limnaeolpium limnatisp. nov.

\section{Diagnosis}

Linnacolpium differ from all other olpiid genera by the following combination of characters: two blades in the cheliceral rallum (Figure 8), reduced eyes (Figure 2), the lack of enlarged tactile setae on the dorsal surface of the pedipalpal femur (Figure 3), and the position of trichobothrium it which is situated on the externo-dorsal face of the fixed chelal finger (Figure 3). Linnaeolpium can be explicitly distinguished from other olpiid genera currently known to occur in Australia as follows: from Beierolpium by the position of trichobothrium st, which is distal to $s b$ in Limnaelpium and dorsal to sb in Beierolpium (e.g. Heurtault 1982; Harvey 1988); and from Euryolpium, Olpium and Xenolpium by the position of trichobothrium est which is clearly basal to it in Euryolpium. Olpium and Xenolpium, but is on approximately the same level as it in Limnacolpinm. There also appears to be unnamed representatives of Indolpium in Australia (Štáhlavský et al. 2006; Harvey, unpublished data), which can be distinguished by the same criterion as Euryolpium, Olpium and Xenolpium.

\section{Description}

\section{Male}

Chelicera: with 5 setae on hand, all setae acuminate; movable finger with 1 subdistal seta; subterminal tooth of movable finger not bifurcate and not enlarged; rallum of 2 or 3 blades, anterior blade smooth except for 2 basal serrations on posterior margin; lamina exterior present, quite broad.

Pedipalp: femur apparently without tactile setae. Fixed chelal finger with 8 trichobothria, movable chelal finger with 4 trichobothria; $c b$, $e b$ and $i s b$ situated basally in straight row; $c b$ and esb closely spaced, less than 1 areolar diameter apart, csb closer to isb than to $e b$; est situated medially on external face of fixed finger, situated midway 
between et and esb; et situated subdistally; ist situated on approximately same level of $i s b ; i b$ situated dorsal to $e b$; st situated closer to chelal finger margin than $b, s b$ and $t$. Venom apparatus present in both chelal fingers, venom ducts very short, terminating in nodus ramosus almost immediately.

Cephalothorax: carapace sub-rectangular; with 1 pair of eye-spots with very flat lenses situated near anterior margin of carapace.

Abdomen: pleural membrane longitudinally striate. Tergites and sternites without any trace of suture line; glandular setae absent. Spiracular helix present.

Genitalia: dorsal anterior glands absent; ejaculatory canal atrium large; with 1 pair of internal glandular setae; median genital sac ovoid.

Legs: junction between femora and patellae I and II broad and apparently mobile; femur I approximately same length as patella I; tibiae III and IV without tactile seta; metatarsi III and IV with long tactile seta situated very close to basal edge; setal formula of metatarsus IV T-1-1-2-1 or T-1-1-3-1 or $\mathrm{T}-0-1-1-3$ or $\mathrm{T}-2-2-3-2$; arolium much longer than claws, not divided.

\section{Etymology}

This genus is named for Carolus Linnaeus (17071778 ), founder of the modern system of taxonomy during the 250th anniversary of the publication of the 10th edition of Systema Naturae (Linnaeus 1758), and combined with the generic name Olpium. It is neuter in gender.

\section{Linnaeolpium linnaei sp. nov.}

Figures 1-12

\section{Material examined}

\section{Holotype}

Australia: Western Australia: ठ, Mesa K

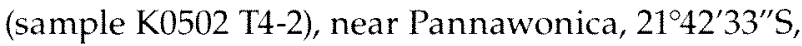
$116^{\circ} 16^{\prime} 16^{\prime \prime} \mathrm{E}, 12$ January 2007, D. Kamien (WAM T82354).

\section{Diagnosis}

Linnaeolpium linnaei is distinguished from all other Australasian olpiids by the reduced eyes.

\section{Description}

Adult male

Body moderately flattened. Colour with sclerotized portions generally very pale, pedipalps and anterior portion of carapace slightly darker.
Chelicera: with 5 setae on hand (Figure 6), all setae acuminate; movable finger with 1 subdistal seta; subterminal tooth of movable finger not bifurcate and not enlarged; with 2 lyrifissures on dorsal face and 1 lyrifissure on ventral face; galea with bifurcate tip and 1 sub-medial ramus; rallum composed of 2 blades, distal blade with 2 basal serrations on posterior margin, basal blade smooth (Figure 8); serrula exterior with 16 blades; lamina exterior present, moderately broad.

Pedipalp: trochanter, femur and patella completely smooth, chela with several large granulations on mesal surface at base of fingers; setae very long and acicular; trochanter elongate, without tubercles; trochanter 2.73, femur 3.47, patella 2.35, chela (with pedicel) 3.60, chela (without pedicel) 3.50 , hand 1.75 times longer than broad, movable finger 1.06 times longer than hand. Femur apparently without long tactile setae. Patella with three lyrifissures situated dorsally near pedicel. Fixed chelal finger with 8 trichobothria, movable chelal finger with 4 trichobothria (Figure 4): $e b$ and $e s b$ situated basally; esb closer to $e b$ than to isb; est slightly basal to $i$; trichobothria $i b$ situated slightly basally to $e b$; ist slightly distal to is $b$; et situated near distal end of finger; ca. 6 microsetae (chemosensory setae) present on fixed finger distal to $e t ; s b$ situated closer to $b$ than to $s t ; t$ situated mid-way between st and tip of movable finger; microsetae (chemosensory setae) not present on movable finger; small "sensory spot" situated slightly distal to $s b$, consisting of single elliptical opening. Venom apparatus present in both chelal fingers, venom ducts very short, terminating in nodus ramosus almost immediately. Chelal teeth obtuse; fixed finger with 25 teeth; movable finger with 23 teeth; accessory teeth absent.

Cephalothorax: carapace (Figure 2) 1.38 times longer than broad; sub-rectangular; with 1 pair of eyespots with flat lenses situated near anterior margin of carapace, posterior pair missing; with 16 setae, arranged 4: 4: 2: 4: 2; without furrows; with 5 pairs of lyrifissures. Manducatory process with 1 long distal, 1 long sub-distal and 2 small internal setae; remainder of maxilla with 6 setae. Chaetotaxy of coxae I-IV: $3: 5: 4: 5$.

Abdomen: pleural membrane longitudinally striate. Tergites and sternites without medial suture. Tergal chaetotaxy: 2: 2: 2: $3:$ : $3:$ : 4: 4: T1T2T1T: 1T2T1: 2; uniseriate; all setae acicular. Sternal chaetotaxy: 6: (0) 2 [1+1] (0): (0) 4 (0): 4: 4: 4: 4: 4: T1T2T1T: 1T1T1T1: 2 ; setae uniseriate and acuminate; glandular setae absent; anus not surrounded by sternite XI.

Genitalia: ejaculatory canal atrium large and rounded; dorsal anterior glands absent; median genital sac ovoid, undivided (Figure 12).

Legs: junction between femora and patellae I and 
II broad and apparently sub-mobile; femur I about same length as patella I; femur + patella of leg IV 3.56 times longer than broad; femora I and II with 2 perpendicular lyrifissures situated sub-distally; tibiae III and IV with 2 moderately long tactile setae, one situated proximally, the other situated sub-medially (Figure 10); metatarsi III and IV with long subbasal tactile seta (Figure 10); metatarsus IV with setal formula of T-1-1-2-1 (i.e. dorsal face with 1 tactile seta and 2 regular setae; ventral face with 2 paired setae; lateral face with 1 seta); tarsus IV with 4 pairs of ventral setae; subterminal tarsal setae arcuate and acute; arolium much longer than claws, not divided (Figures 9-11).

Dimensions ( $\mathrm{mm}$ ): Male holotype: Body length 1.32. Pedipalps: trochanter $0.192 / 0.070$, femur $0.288 / 0.083$, patella $0.250 / 0.106$, chela (with pedicel) $0.461 / 0.128$, chela (without pedicel) 0.448 , hand length 0.224 , movable finger length 0.237 . Chelicera $0.115 / 0.064$, movable finger length 0.090. Carapace $0.176 / 0.128$; eye diameter 0.003 . Leg I: femur not

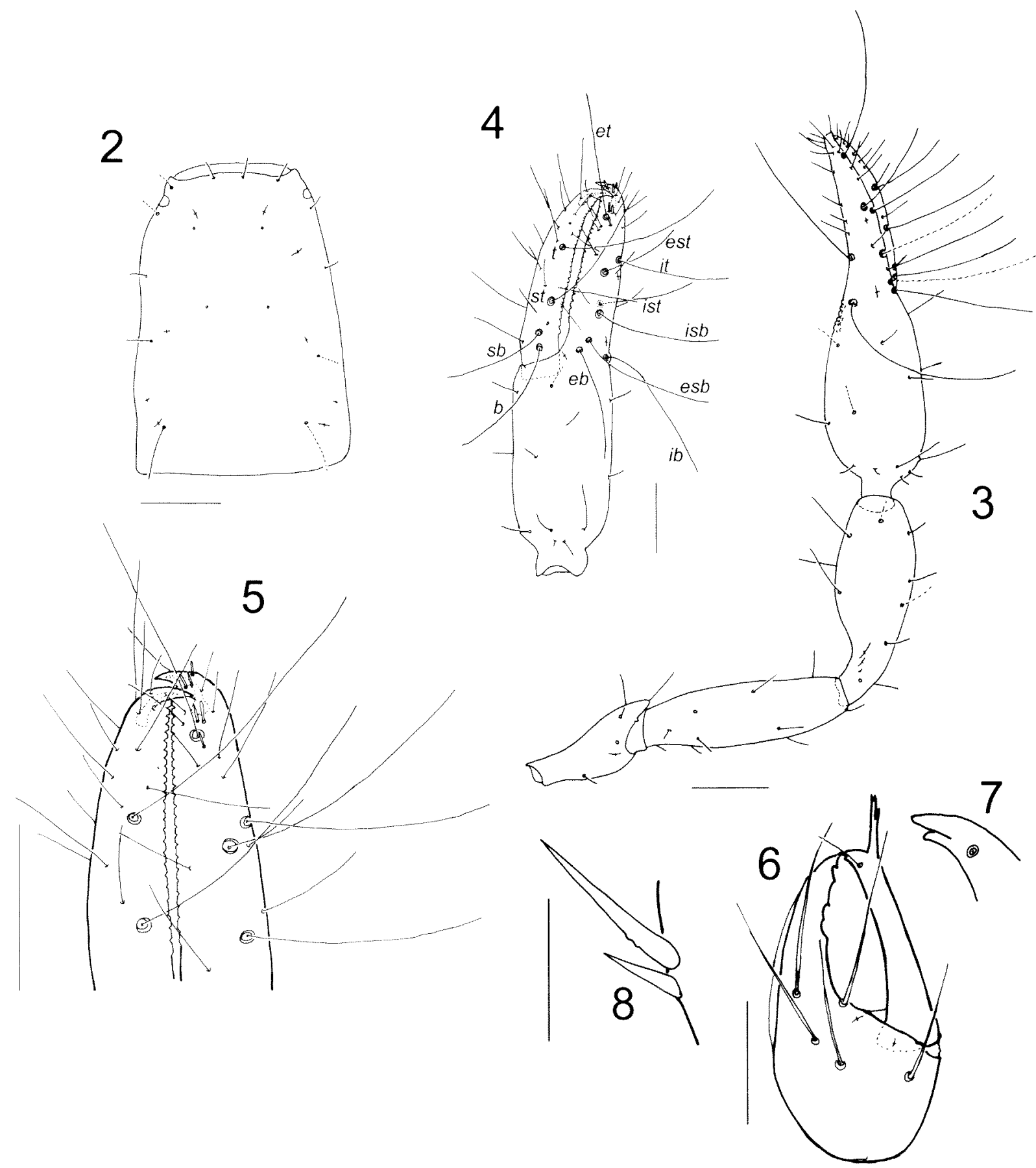

Figures 2-8 Limnatolpinm linnat sp. nov, holotype male (WAM T82354): 2, carapace, dorsal aspect; 3, right pedipalp. dorsal aspect; 4 , left chela, lateral aspect; 5 , left chelal fingers, detail; 6 , right chelicera, dorsal aspect; 7 , tip of movable cheliceral finger, dorsal aspect; 8, right rallum, lateral aspect. Scale lines $=0.1 \mathrm{~mm}$ (Figures 2-5), 0.5 $\mathrm{mm}$ (Figure 6), 0.25 (Figure 8). 
measurable, patella $0.180 / 0.076$, tibia $0.255 / 0.077$, metatarsus $0.102 / 0.061$, tarsus $0.128 / 0.051$. Leg IV: femur + patella $0.249 / 0.070$, tibia $0.173 / 0.047$, metatarsus $0.058 / 0.040$, tarsus $0.090 / 0.031$.

\section{Remarks}

Linnaeolpium linnaei is currently known from only a single location in north-western Western Australia where it was taken from a litter trap within a pisolite mesa, and as such can be readily characterised as a short-range endemic species as defined by Harvey (2002). The specimen displays some troglomorphic features such as reduced eyes and pallid colouration. Despite having examined numerous Australian olpiines from a wide variety of habitats, we have not seen any specimens apart from the holotype of $L$. limnaei that bears reduced eyes. Other troglobitic pseudoscorpions have been recently recorded from the pisolitic mesas situated near Pannawonica, including Tyrannochthonius basme Edward and Harvey 2008 and Lagynochthonius asema Edward and Harvey 2008 (Chthoniidae) (Edward and Harvey 2008), Indohya sp. (Hyidae) (Harvey and Volschenk 2007), and Ideoblothrus pisolitus Harvey and Edward 2007, I. linnaei Harvey and Leng 2008, and I. sp. Mesa A (Syarinidae) (Harvey and Edward 2007a; Harvey and Leng 2008). All of these species
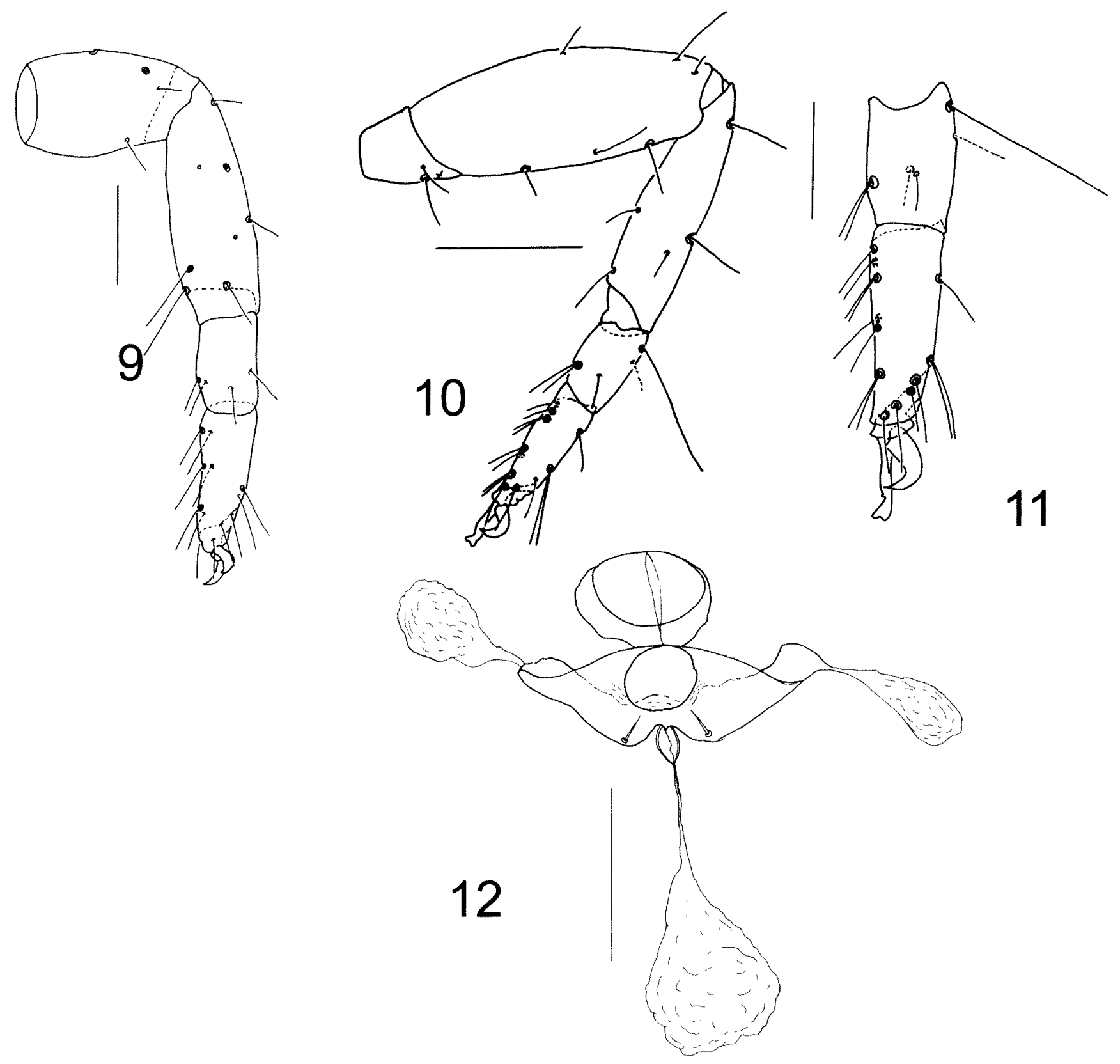

Figures 9-12

Linnaeolpium linnaei sp. nov., holotype male (WAM T82354): 9, left leg I, patella-tarsus, lateral aspect; 10, left leg IV, lateral aspect; 11, left leg IV, metatarsus and tarsus. Scale lines $=0.1 \mathrm{~mm}$ (Figure 10), $0.5 \mathrm{~mm}$ (Figures 9 , 11), 0.05 (Figure 12). 
exhibit troglomorphic morphological features, as do other troglobitic arachnids recorded from the region including an oonopid spider (Harvey and Edward 2007b) and several schizomids (Harvey it al. 2008).

\section{Etymology}

This species is named for Carolus Linnaeus (1707-1778).

\section{ACKNOWLEDGEMENTS}

This study was funded by Robe River Iron Associates and Chevron (Gorgon), and was kindly facilitated by Garth Humphreys of Biota Environmental Sciences. The specimen examined in this study was kindly provided by Garth Humphreys and Dan Kamien of Biota Environmental Sciences. We are very grateful to two anonymous referees for their helpful comments on the manuscript.

\section{REFERENCES}

Beier, M. (1932). Pseudoscorpionidea I. Subord. Chthoniinea et Neobisinea. Therrich 57: i-xx, 1-258.

Chamberlin, J.C. (1930). A synoptic classification of the false scorpions or chela-spinners, with a report on a cosmopolitan collection of the same. Part II. The Diplosphyronida (Arachnida-Chelonethida). Annals and Magazine of Natural History (10) 5: 1-48, 585-620.

Chamberlin, J.C. (1931). The arachnid order Chelonethida. Stanfort University Publications, Biological Scinces $7(1)$ : $1-284$.

Edward, K.L. and Harvey, M.S. (2008). Short-range endemism in hypogean environments: the pseudoscorpion genera Tyrannochthonius and Lagynochthonius (Pseudoscorpiones: Chthoniidae) in the semiarid zone of Western Australia. Invertebrate Systematics 22: 259-293

Harvey, M.S. (1988). Pseudoscorpions from the Krakatau Islands and adjacent regions, Indonesia (Chelicerata: Pseudoscorpionida). Memoirs of the Museum of Victorin 49: 309-353

Harvey, M.S. (1992). The phylogeny and classification of the Pseudoscorpionida (Chelicerata: Arachnida). Ineverthate Thxonomy 6: 1373-1435.

Harvey, M.S. (2002). Short-range endemism in the Australian fauna: some examples from non-marine environments. Inertebrate Systematios 16: 555-570.

Harvey, M.S., Berry, O., Edward, K.L. and Humphreys, G. (2008). Molecular and morphological systematics of hypogean schizomids (Schizomida: Hubbardiidae) in semi-arid Australia. Inertelrate Systematics 22: 167 194.

Harvey, M.S. and Edward, K.L. (2007a). A review of the pseudoscorpion genus heoblothrs (Psendoscorpiones, Syarinidae) from western and northern Australia. joumal of Natural History $41: 445-472$

Harvey, M.S. and Edward, K.L. (2007b). Three new species of cavernicolous goblin spiders (Araneat: Oonopidae) from Austratia. Records of the Westem Australim Musum 24: 9-17.

Harvey, M.S. and Leng, M.C. (2008). Further observations on litoblothms (Pseudoscorpiones: Syarinidae) from subterranean environments in Australia. Records of the Westem Australian Musenm 24: 381-386.

Harvey, M.S and Volschenk, E.S. (2007). The systematics of the Gondwanan pseudoscorpion family Hyidae (Pseudoscorpiones: Neobisioidea): new data and a revised phylogenetic hypothesis. metertebrat Sistematics 21: 365-406

Heurtault, J. (1979). Complément à la description de Olpimm pallipes Lucas, 1845, type de la famille Olpiidae (Arachnides, Pseudoscorpions). Reirte' Sutsist de Zoologie 86: 925-931.

Heurtault, I. (1980a). Complément à la description do Minniza aermis Simon, 1881, espece-type du genre (Arachnides, Pseudoscorpions, Olpiidae). Bulletin du Musíum National d'Histoire Naturelle, Paris (4) 2: 175 184.

Heurtault, 1. (1980b). Données nouvelles sur les genres Xenolpium, Antiolpium, Indolpium et Euryolpium (Arachnides, Pseudoscorpions). Recur Suisse de Zoologite 87: 143-154.

Heurtault, J. (1982). Le développement postembryonnaire chez deux especes nouvelles de Pseudoscorpions Olpiinae du Venezuela. Rerue de Nordest Biologie 3 : 57-85.

Heurtault, J. and Rebiere, J. (1983). Pseudoscorpions des Petites Antilles. I. Chernetidae, Olpiidae, Neobisiidae, Syarinidae. Bulletin du Musium National d'Histoire Naturell', Paris (4) 5: 591-609.

Hoff, C.C. (1945). The pseudoscorpion subfamily Olpiinae. American Muselum Nozitates 1291: 1-30.

Hoff, C.C. (1964). The pseudoscorpions of Jamaica. Part 3 The suborder Diplosphyronida. Bulletin of the Institute of Jamaica, Scionce Series 10(3): 1-47.

Judson, M.L.I. (1992). African Chelonethi. Studies on the systematics, biogeography and natural history of African pseudoscorpions (Arachida). Ph.D. thesis, Department of Pure and Applied Biology, University of Leeds: Leeds.

Judson, M.L.I. (1993). African Chelonethi: studies on the systematics, biogeography and natural history of African pseudoscorpions (Arachnida) [Abstract]. Index to theses, with abstracts, accopted for higher degrees by the uniersitis of Great Britain and lreland 42: 697.

Judson, M.L.I. (2005). Baltic amber fossil of Garypimus electri Beier provides first evidence of phoresy in the pseudoscorpion family Garypinidae (Arachnida: Chelonethi). In Logunov, D.V and Penney, D. (eds), European Arachology 2003 (Procedings of the 21 st Europen Collogumm of Aratmology, St.-Petersburg to Alsust 20(03): 127-131. Moscow: KMK Scientific Press Ltt.

Judson, M.L.I. (2007). A new and endangered species of the pseudascorpion genus Lagymodithonits from a cave in Vietnam, with notes on chelal morphology and the composition of the Tyrannochthonini (Arachnida, Chelonethi, Chthoniidae). Zootax 1627: 53-68.

Linnaeus, C. (1758). Systema naturat, 10th edition. Vol 1 L. Salvii: Holmiae.

Mahnert, V. (1984). Pseudoscorpions (Arachnida) récoltes durant la mission spéologique espagnole au Pérou en 1977. Renu' Arachologigue 6: 17-28. 
Mahnert, V. (1986). Une nouvelle espèce du genre Tyrannochthonius Chamb. des îles Canaries, avec remarques sur les genres Apolpiolum Beier et Calocheirus Chamberlin (Arachnida, Pseudoscorpiones). Mémoires de la Société Royale Entomologique de Belgique 33: 143153.

Mahnert, V. (1991). Pseudoscorpions (Arachnida) from the Arabian Peninsula. Fauna of Saudi Arabia 12: 171-199.

Mahnert, V. (2001). Cave-dwelling pseudoscorpions (Arachnida, Pseudoscorpiones) from Brazil. Revue Suisse de Zoologie 108: 95-148.

Mahnert, V. (2002). Two new species of pseudoscorpions (Arachnida, Pseudoscorpiones) from caves on Tenerife and La Palma (Canary Islands, Spain), with some new records from the Canary Islands and the Azores (Portugal). Revue Suisse de Zoologie 109: 777-784.

Muchmore, W.B. (1979). Pseudoscorpions from Florida and the Caribbean area. 7. Floridian diplosphyronids. Florida Entomologist 62: 193-213.

Muchmore, W.B. (1986). Redefinition of the genus Olpiolum and description of a new genus Banksolpium (Pseudoscorpionida, Olpiidae). Journal of Arachnology 14: 83-92.
Murienne, J., Harvey, M.S. and Giribet, G. (2008). First molecular phylogeny of the major clades of Pseudoscorpiones (Arthropoda: Chelicerata). Molecular Phylogenetics and Evolution 49: 170-184.

Stáhlavský, F., Král, J., Harvey, M.S. and Haddad, C.R. (2006). A karyotype study on the pseudoscorpion families Geogarypidae, Garypinidae and Olpiidae (Arachnida: Pseudoscorpiones). European Journal of Entomology 103: 277-289.

Tooren, D. van den (2002). Pseudoscorpions (Pseudoscorpiones: Olpiidae) of the genus Apolpium from Venezuela, and the genera Pachyolpium, Leptolpium gen. nov. and Serianus from Curaçao, Aruba and Bonaire. Zoologische Mededelingen 76: 141-192.

Manuscript received 26 May 2008; accepted 3 October 2008 